\title{
International Registration of Cultivar Names for Unassigned Woody Genera July 2006-December 2009
}

\author{
Gerry Moore \\ Brooklyn Botanic Garden, 1000 Washington Avenue, Brooklyn, NY 11225-1099, USA
}

\begin{abstract}
During the period July 2006 to December 2009, eight cultivar names in unassigned woody genera were registered. Individuals introducing new cultivars of ornamental plants are encouraged to register these names with a view to nomenclatural stabilization. A directory of International Registration Authorities and list of the unassigned woody genera is available from the American Public Gardens Association, 351 Longwood Road, Kennett Square, PA 19348, U.S.A <www.ishs.org/sci/icra.htm>. A database for all previously registered cultivar names for unassigned woody genera is maintained by Brooklyn Botanic Garden <www.bbg.org/sci/taxonomy/registration.html>. The present International Registration Authority for unassigned woody ornamentals can be contacted at the address above.
\end{abstract}

Callicarpa dichotoma 'Duet'. Registered 23 October 2007. Registrant: Sandra M. Reed, U.S. National Arboretum, USDA-ARS, 472 Cadillac Lane, McMinneville, TN 37110, U.S.A. Callicarpa dichotoma 'Duet' originated as a sport of Callicarpa dichotoma 'Albifructus' and was found at the Tennessee Technological University (Cookeville, TN) by Gary Bachman and Edgar Davis. This new cultivar differs from C. dichotoma cultivars by having variegated (green and light gold) foliage and white berries. Occasional reverent shoots are observed, but the variegation pattern is very stable. This cultivar has been tested by the U.S. National Arboretum (McMinnville, TN) and jointly released by the U.S. National Arboretum and the Tennessee Technological University in November 2006. It has been assigned the Plant introduction number PI651521. A specimen has been deposited at the U.S. National Arboretum Herbarium (NA).

Fagus grandifolia 'Ferncliff'. Registered 16 June 2006. Registrant: Brian P, Riley, ODNR-Division of Forestry, 2045 Morse Rd., Bldg. H-1, Columbus, OH 43229. Fagus grandifolia 'Ferncliff' originated as a chance wild seedling in what is currently the east side of section H of Ferncliff Cemetery and Arboretum, 501 W. McCreight Ave., Springfield, OH. The new cultivar was first observed by Brian P. Riley in March 2001 as a mature tree, aged approximately 125 years. It is distinguished by having bark that is shallowly fissured into conspicuous diamond shapes even down to twigs 1-1.5 cm thick, and which resembles that of an Amelanchier sp. The new cultivar also has particularly dark green, glossy foliage. The original tree occurs in an open environment and has developed a compact dome-shaped crown of elegant, arching branches. If an infraspecific taxonomy within Fagus grandifolia is recognized, 'Ferncliff' would be placed in Fagus grandifolia Ehrh. var. grandifolia. Fagus grandifolia 'Ferncliff' is propagated via grafting onto Fagus grandifolia understock (attempts using $F$. sylvatica as understock have not been successful), and is being commercially introduced by a select few nurseries in Ohio, as well as Heritage Seedlings Inc. in Salem, Oregon. The trademark name Diamondbark American Beech has been accepted and was approved on July 24, 2007, by the United States Patent and Trademark Office (Registration No. 3,270,662). Diamondbark American Beech ${ }^{\mathrm{TM}}$ is a registered trademark of Ferncliff Cemetery \& Arboretum, Springfield, Ohio. A cultivar standard, including photographs, of Fagus grandifolia 'Ferncliff' has been deposited at the Brooklyn Botanic Garden Herbarium (BKL).

Forsythia $\times$ intermedia 'Rebel'. Registered 29 June 2007. Registrant: Richard A. Larson, The Dawes Arboretum, 7770 Jacksontown Rd. SE, Newark, OH 43056. Forsythia $\times$ intermedia 'Rebel' is a selection first observed in 1995 at The Dawes Arboretum. This cultivar has a wide array of variegation ranging from nearly yellow leaves flushed with light green to dark green irregular blotches in the center surrounded by lemon yellow tissue. Some leaves are pure yellow, some yellow green and others solid green. A specimen standard, including photographs, for this cultivar has been deposited at the Brooklyn Botanic Garden Herbarium (BKL).

Gardenia augusta “Torgaa”. 15 June 2009. Registrant: Doug Torn, 7501 U.S. Highway 29 N., Brown Summit, NC 27214. Gardenia augusta 'Torgaa' is a selection first observed in 1993 at Davie, FL. It was first propagated in 1995 and flowered in 1996. It was first sold commercially in 2009 in North Carolina by Buds \& Blooms Nursery, Inc. This cultivar goes under the trademark name "Summer Snow". It exhibits compact, semidwarf growth, and possesses large, double, fragrant flowers and large evergreen leaves. This cultivar can be distinguished from other cultivars in Gardenia augusta on the basis of its extremely large (up to $10 \mathrm{~cm}$.) double, fragrant flowers and large evergreen, glossy leaves. It is also quite cold hardy surviving up to zone 7a (U.S.D.A. 2003 Hardiness Zone map), and can be grown in partial shade or sun.

Populus 'Okanese'. Registered 12 October 2006. Registrant: Bill Schroeder, AAFCA-PFRA Shelterbelt Centre, Box 9040, Indian Head, Saskatchewan, S0G 2K0, Canada. Populus 'Okanese' is a cross between Populus 'Walker' and P. petrowskyana 'Russan poplar' This material is from a male clone. It has a moderately straight bole and is occasionally multi-stemmed. This cultivar has shown excellent resistance to disease and insect problems, such as bud gall mite, cytospora, septoria canker, and melamspora leaf rust. It is also cold hardy, drought tolerant, and disease resistant. It also appears to be widely adapted for planting in the Canadian prairies, especially in the aspen parkland and boreal transition ecoregions.

Spiraea 'Holehird'. Registered 30 March 2008. Registrant: Vicky Aspin, Half Island House, Beckfoot, Lowgill, Kendal Cumbria LA8 OBL, United Kingdom. Spiraea 'Holehird' is a selection that was first encountered in 2005 at the Lakeland Horticultural Society Garden. Four year old individuals of this cultivar reach heights of up to $2.5 \mathrm{~m}$. with an upright to arching habit with a spread of up to $1.5 \mathrm{~m}$. The cultivar has a moderately vigorous growth rate, leaves glaucous up to $8.0 \times 3.5 \mathrm{~cm}$., margin toothed especially towards the apex, often flushed with red when emerging, stems reddish brown to shining brown, flowers densely clustered in large corymbs $(7-16 \times 6-12 \mathrm{~cm}$.), petals 5 , rounded, pale pink fading to nearly white, sepals 5, reddish green, filaments numerous, long, white/pinkish to white, anthers pale pink, styles 5, flower buds pink. This cultivar appears to have (combine?) attributes of Spiraea betulifolia and S. japonica var. fortunei that grow nearby. A specimen of this cultivar has been deposited at Brooklyn Botanic Garden Herbarium (BKL).

Viburnum nudum 'Longwood'. Registered 11 February 2008. Registrant: Tomasz Aniśko, Longwood Gardens, P.O. Box 501, Kennett Square, PA 19348-0501. Viburnum nudum 'Longwood' is a selection first observed in the wild in 2006. This cultivar is a dense compact shrub with glossy leaves that turn a rich wine red color in the fall; it has proflific fruit set. It differs from the species in its more compact growth, glossier leaves, and more prolific fruit set. A specimen of this cultivar has been deposited at the Brooklyn Botanic Garden Herbarium (BKL).

Weigelia 'Purity'. Registered 17 September 2006. Registrant: Jean-François Devoyault, 1070 rang 1 ouest, Sainte-Christine, Qc, Canada, J0H 1H0. Weigelia 'Purity' originated from a controlled cross between Weigelia 'Polka' and Weigelia 'Bristol Snowlake' made in 1999. This new cultivar is distinguished from its parents by its pure white flowers and its tolerance to colder temperatures (zones 4 to 8 , Canadian hardiness map). Weigelia 'Purity' was first released commercially in 2006 by Au Jardin de Jean-Pierre Inc. Photographs of this cultivar has been deposited at the Brooklyn Botanic Garden Herbarium (BKL). 